\title{
Influence of autotroph model complexity on simulations of microbial communities in marine mesocosms
}

\author{
J. R. Dearman ${ }^{1}$, A. H. Taylor ${ }^{2}$, K. Davidson ${ }^{1, *}$ \\ ${ }^{1}$ Scottish Association for Marine Science, Dunstaffnage Marine Laboratory, Oban, Argyll PA37 1QA, Scotland, United Kingdom \\ ${ }^{2}$ Plymouth Marine Laboratory, Prospect Place, West Hoe, Plymouth PL1 3DH, United Kingdom
}

\begin{abstract}
Marine mesocosm experiments were conducted using a natural phytoplankton assemblage from the Tromsheim fjord, Norway, in June 2000. Replicate experiments were conducted at 2 inorganic nitrogen:silicon ( $\mathrm{N}: \mathrm{Si})$ molar ratios, 4:1 and 1:1. Time course changes in the different groups that comprised the microplanktonic community and inorganic nutrient concentrations were recorded. We sought to simulate these data using 3 alternative mathematical models based on a common framework of functional groups and inter-group interactions following an earlier model. The functional groups incorporated within the model were bacteria, diatoms, dinoflagellates, phytoflagellates, picophytoplankton, heteroflagellates and larger microzooplankton along with inorganic nutrients, dissolved organic matter and detritus. We modified the autotroph functional group submodels to achieve different levels of model sophistication in terms of utilisation of nutrients (single $[\mathrm{N}]$ or dual [N:Si] inorganic nutrient models) and organism structure (biomass growth made a function or extracellular or intracellular nutrient concentration). We tested the influence of different model formulations on simulations of particulate carbon (C) biomass and its partitioning amongst the microbial groups in the 2 different experimental nutrient regimes. To achieve satisfactory global simulations (both nutrient regimes) with a single-parameter set, it was found necessary to include a dual currency of both inorganic $\mathrm{N}$ and $\mathrm{Si}$ in the model, and to relate $\mathrm{C}$ biomass growth to the intracellular rather than extracellular concentration of the nutrient in the least relative supply. Models lacking these 2 features were unable to simulate $\mathrm{N}$ and $\mathrm{Si}$ and $\mathrm{C}$ biomass dynamics of the microbial assemblage in alternative conditions of high and low $\mathrm{N}$ :Si ratio.
\end{abstract}

KEY WORDS: Microbial food-web model $\cdot$ Nitrogen:silicon $\cdot$ Cell quota $\cdot$ Autotrophs

Resale or republication not permitted without written consent of the publisher

\section{INTRODUCTION}

In the light of our ever-increasing understanding of marine ecosystems, it is necessary to critically analyse the fundamental building blocks and pathways included within mathematical models, particularly of coastal regimes, where the influence of anthropogenic nutrient loading is of concern. Traditionally, models of marine ecosystems have relied on a simple nutrientphytoplankton-zooplankton (N-P-Z) structure (Steele 1974). The 'discovery' of the microbial loop (Azam et al. 1983) led the way towards an improvement in understanding the interactions within microbial food webs

*Corresponding author. Email: kda@dml.ac.uk (e.g. Sherr et al. 1984, Suttle et al. 1986, Azam 1998). This, in combination with increasing computing power, has led to refinement of pelagic food-web model structure, with various 'new' functional groups being introduced into models as an ongoing process. The nearclassic model of Fasham et al. (1990) is an excellent example of a model that incorporates some of our new understanding of the complexity of the marine microbial food web. Numerous refinements of this and similar models have occurred subsequently (Haney \& Jackson 1996, Fasham et al. 1999, Spitz et al. 2001).

A common strategy when building biological ecosystem models is to relate the specific rate of cell division 
or biomass increase to the local concentration of the assumed least-abundant (limiting) nutrient based on Monod-style kinetics (Monod 1942) incorporating a Michaelis-Menten style hyperbola or some modification thereof (Fasham et al. 1990, Taylor et al. 1993, Baretta-Bekker et al. 1994). In many marine systems, experimental evidence suggests that nitrogen $(\mathrm{N})$ is the limiting nutrient (Officer \& Ryther 1980).

In coastal marine systems, silicon ( $\mathrm{Si}$ )-requiring diatoms play a particularly important role within the plankton, forming the greater part of the spring phytoplankton bloom in temperate latitudes. Si is also important in the open ocean. Although variations exist, diatoms require $\mathrm{N}$ and $\mathrm{Si}$ in approximately equal quantities (Schöllhorn \& Granéli 1996). Hence, although nutrient affinity is also important, should there be a relative lack of $\mathrm{Si}$, then $\mathrm{Si}$ - rather than N-limitation of the growth of the diatom population may occur (Officer \& Ryther 1980, Conley et al. 1993, Conley 1997).

The anthropogenic $\mathrm{N}$ loading that occurs in many coastal waters may be increasing the inorganic N:Si ratio (Jickells 1998, Egge \& Asknes 1992, Sommer 1994), especially in regions of restricted exchange (Rahm et al. 1996, Aure et al. 1998) potentially resulting in a switch from N- to Si-limitation of diatoms. Silimitation may influence the species composition of a diatom assemblage (Sommer 1986, 1991) and change the species composition of the microbial assemblage as a whole, producing a flagellate- rather than diatomdominated community (Officer \& Ryther 1980, Smayda 1990, Egge \& Asknes 1992). Changes in the diatom and autotrophic flagellate populations will influence the quantity, type and quality of autotrophic food available to both micro- and meso-heterotrophic grazers. Si-limitation of the diatom assemblage may therefore have significant implications for the dynamics of microbial food webs and the flux of carbon (C) and $\mathrm{N}$ in pelagic food webs in general.

As noted by Davidson (1996), Haney \& Jackson (1996) and Tett \& Wilson (2000) the level of physiological detail incorporated within models has varied markedly between different studies. Yet although numerous different microbial food-web model formulations exist, there is a surprising paucity of discussion regarding the implications of these different formulations (Tett \& Wilson 2000). Should we choose to incorporate multiple nutrients in a model, the simplest approach is to relate biomass growth rate to the concentration of extracellular nutrient in least relative supply. However, as noted by Baretta-Bekker et al. (1998), the inclusion of luxury nutrient uptake of a second, non-limiting nutrient and the decoupling of carbon (C) and nutrient dynamics (Lancelot \& Billen 1985, Davidson 1996, Haney \& Jackson 1996, BarettaBekker et al. 1998) may influence microbial food-web dynamics. Hence, some representation of intracellular nutrient concentration may be necessary to quantitatively simulate the changes in biomass of different microbial groups.

If our goal is to produce global models capable of simulating a range of environmental conditions, then it may be necessary to routinely simulate both diatoms and non-diatomous autotrophs and to include multiple inorganic and organic nutrients within our formulations (Flynn et al. 1997). In this paper we test this hypothesis using a single-model framework in terms of physical and biological interactions, microbial functional groups and species-species interactions, i.e. the model of Taylor et al. (1993). Using this framework, we assessed the predictive ability of microbial ecosystem models of varying levels of sophistication in terms of nutrient currency and autotroph sub-model sophistication when applied to marine microbial mesocosm data sets under different $\mathrm{N}$ :Si nutrient regimes. In particular, we determined the ability of models of different levels of sophistication to simulate, using a single parameter set, a single microbial assemblage that was subject to alternative inorganic nutrient regimes. Hence, we sought to gain an appreciation of the global applicability of model structure, rather than the simple ability to fit a single data set.

The model was formulated to simulate the production of organic $\mathrm{C}$ biomass as a function of inorganic nutrient availability, and differentiated between 4 different autotroph groups (1 diatom and 3 non-diatom) along with various heterotrophs and other biological state variables. Alternative versions of the model included simulations of autotrophs at 3 levels of sophistication: (1) single-nutrient (N) and Monod-style growth; (2) dual nutrient $(\mathrm{N}, \mathrm{Si})$ and Monod-style growth; (3) dual nutrient $(\mathrm{N}, \mathrm{Si})$ and modified quota (Caperon 1968, Droop 1968) style growth, in which C biomass increase is related to the intracellular concentration of nutrient in the least relative supply.

To test the models, we simulated data collected from a suite of mesocosm experiments conducted on a natural microbial assemblage. The controlled conditions of mesocosms are increasingly being used to formulate and test mathematical models (Baretta-Bekker et al. 1998, Thingstad \& Havskum 1999, Watts \& Bigg 2001). Here, experiments were conducted using 2 different supply ratios of inorganic $\mathrm{N}$ and $\mathrm{Si}$ to produce conditions in which the diatom population was thought to be $\mathrm{N}$ and $\mathrm{Si}$ yield-limited respectively.

We investigated the influence of changes in model sophistication on simulations of the biomass distribution between different microbial groups and of the food web as a whole to assess the benefits of increased model sophistication set against the related problems of parameterisation of more physiologically detailed 
models. In particular we sought to determine (1) whether we could model a coastal planktonic ecosystem under 2 alternative nutrient (N:Si) regimes, using a single model and a single parameterisation thereof, and (2) the minimum level of complexity in terms of nutrient currency and modelled autotroph functional-group physiology required to achieve this.

\section{MATERIALS AND METHODS}

Mesocosm experiments were conducted on a natural planktonic assemblage from Tromsheim Fjord, Norway, in June 2000. An outline of the methodology is given below.

Experiments were conducted in $1.5 \mathrm{~m}^{3}$ mesocosm bags (1.5 m depth and $1 \mathrm{~m}^{2}$ surface area) suspended in an outdoor seawater basin within the Trondheim Marine systems large-scale facility. Natural surface seawater (with a mean nutrient concentration of $4 \mu \mathrm{M}$ nitrate and $1.5 \mu \mathrm{M}$ silicate) was diluted with planktonfree deep water $(\sim 180 \mathrm{~m}$, mean nutrient concentration of $13 \mu \mathrm{M}$ nitrate, $5.3 \mu \mathrm{M}$ silicate) and enriched by the addition of inorganic nutrients (nitrate, silicate and excess phosphate) to obtain different inoculum nutrient (N:Si) concentration ratios of approximately $4: 1$ (28 $\mu \mathrm{M}: 7 \mu \mathrm{M})$ and 1:1 (12 $\mu \mathrm{M}: 12 \mu \mathrm{M})$ respectively, henceforth referred to as 'high $\mathrm{N}: \mathrm{Si}^{\prime}$ and 'low $\mathrm{N}: \mathrm{Si}^{\prime}$ respectively. A total of 8 bags were studied, 4 for each nutrient regime.

The Si requirements of diatoms are quite variable (Paasche 1973, Olsen \& Paasche 1986, Sommer 1986, 1991, Schöllhorn \& Granéli 1996), but on average a diatom community may be expected to require $\mathrm{N}$ and $\mathrm{Si}$ in an approximately equal molar ratio (Redfield 1963, Brzezinski 1985, Schöllhorn \& Granéli 1996). Hence, the different N:Si nutrient regimes studied produced fundamentally different forms of diatom nutrient limitation with Si-limitation being induced at the high N:Si ratio (L. C. Gilpin et al. unpubl. data).

The mesocosms ran in 'batch' mode until Day 6 to allow the populations to become established. Following this, every $2 \mathrm{~d}$ a fraction, $k$, of $20 \%$ of the total volume was removed by pumping and replaced with a combination of fjord surface and deep water (in the same volume ratio and manipulated to achieve the same nutrient concentrations as were apparent in the mesocosms at time zero). The mesocosms therefore ran as semi-continuous cultures, such methodology allowing prolonged duration of active cell growth (Williams \& Egge 1998) and better simulating the conditions that may be encountered by coastal microplankton.

Samples were collected every $2 \mathrm{~d}$ to determine the cell densities of the various groups within the mesocosms: bacteria, diatoms, photosynthetic nanoflagellates
(PNAN), heterotrophic nanoflagellates (HNAN), autotrophic and heterotrophic dinoflagellates, and larger microzooplankton. Extracellular inorganic nutrient concentrations $\mathrm{NH}_{4}, \mathrm{NO}_{3}, \mathrm{PO}_{4}, \mathrm{SiO}_{4}$ were assessed. Total particulate $\mathrm{C}$ and $\mathrm{N}$ contents were determined, and $\mathrm{C}$ biomass of the different microbial groups was estimated from each experiment based on mean cell volume, MCV (Montagnes et al. 1994, Davidson et al. 2002).

Modelling methods and framework. The model structure used for all our simulations was the single mixed-layer model developed by Taylor et al. (1993). The model makes autotroph growth a combined function of light and nutrient availability, with vertical changes in light intensity being calculated using the 2-waveband approximation of Taylor et al. (1991) based on Carr (1986). The physical framework of the model was adapted to account for the conditions within the mesocosms. These were a restricted depth of $1.5 \mathrm{~m}$, no loss of cells from the enclosure due to sinking or mixing, and a semi-continuous removal of cells and water and replacement with new water and nutrients. The physical conditions are outlined in Table 1.

Within this physical framework the time-dependent biological ecosystem model, also of Taylor et al. (1993), was incorporated, the structure of which is shown in Fig. 1. The trophic relationships of this model are based on those in the microbial food web of Azam et al. (1983). The model is composed of 4 classes of autotrophs: diatoms $\left(P_{d}\right)$, dinoflagellates $\left(P_{n}\right)$, phytoflagellates $\left(P_{f}\right)$, picophytoplankton $\left(P_{C}\right)$; and 3 classes of heterotrophs: free bacteria $(B)$, heteroflagellates $\left(H_{f}\right)$, and larger microzooplankton $(Z)$. Autotrophs take up inorganic nutrients, and loss terms are included to account for the production of non-living organic matter as metabolisable dissolved organic carbon $(D)$; and detritus $\left(D_{T}\right)$.

In this study, only the equations simulating autotrophs and inorganic nutrient concentrations have been changed from those of Taylor et al. (1993), and these will be presented in full below. In all versions of

Table 1. Measured physical and initial chemical conditions used in the operation of the models. Water renewal of $20 \%$ of total volume was employed semi-continuously every $2 \mathrm{~d}$ from Day 6 onwards, giving a mean renewal of $10 \%$ per day

\begin{tabular}{|lcc|}
\hline Parameter & \multicolumn{2}{c|}{$\mathrm{N}: \mathrm{Si}$} \\
& High & Low \\
\hline Nitrate conc. $\left(\mathrm{mmol} \mathrm{m}^{-3}\right)$ & 26 & 12 \\
Silicate conc. $\left(\mathrm{mmol} \mathrm{m}^{-3}\right)$ & 6 & 12 \\
Ammonium conc. $\left(\mathrm{mmol} \mathrm{m}^{-3}\right)$ & 0.1 & 0.1 \\
Temperature $\left({ }^{\circ} \mathrm{C}\right)$ & 10.5 & 10.5 \\
Depth $(\mathrm{m})$ & 1.5 & 1.5 \\
Water renewal $(k)$ & 0.2 & 0.2 \\
No. of days & 16 & 16 \\
\hline
\end{tabular}




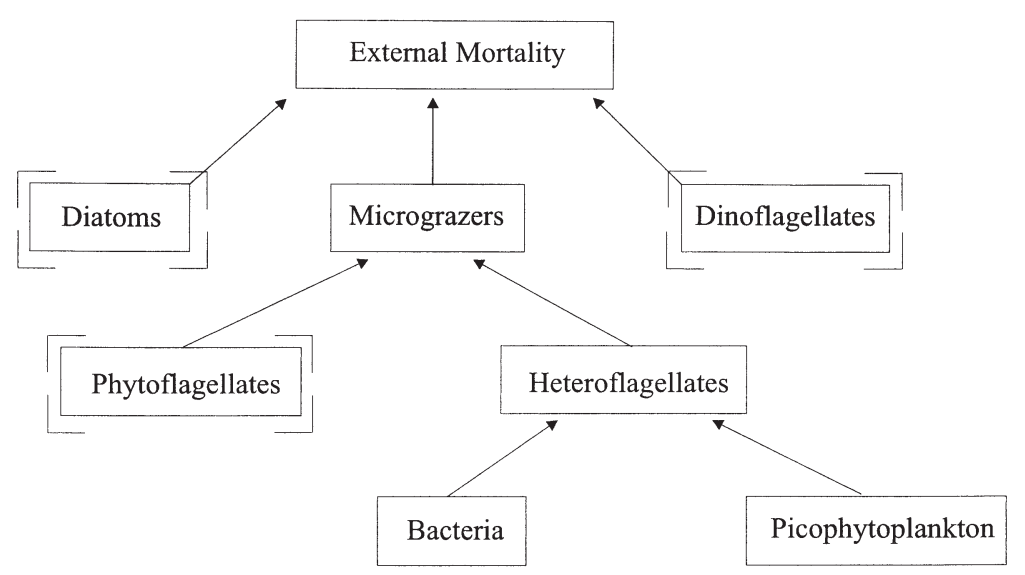

Fig. 1. Schematic diagram of model structure used as the basis of our 3 microbial models. Model also includes silicate, nitrate, ammonium, DOC and detritus

the model studied, heterotrophs and organic pools are treated in the same way and in an identical manner to that of Taylor et al. (1993), who has explained the equations in detail. Hence, only a brief description of the equations in Table 2 relating to heterotrophs is presented here:

Bacterial equation (Table 2, Eq. T5): The model assumes bacterial growth rate to be related to the availability of DOC $(D)$, governed by a rectangular hyperbolic equation, where $\phi_{d}$ is the degree of limitation and $D_{h}$ the half-saturation constant.

Heteroflagellate and microzooplankton equations (Table 2, Eqs. T6 \& T7): The growth rates of the het- eroflagellates and microzooplankton (governed by the transfer coefficients $a_{X Y}$ where $x$ is the predator and $y$ the prey) were each made directly proportional to the concentration of multiple food sources: picophytoplankton, bacteria and detritus in the case of heteroflagellates, and phytoflagellates, heteroflagellates and detritus in the case of microzooplankton. The coefficient (Cil in Table 3) defines the ratio of grazing rates of larger microzooplankton to heteroflagellates (see Taylor \& Joint 1990 or Taylor et al. 1993 for a full description). Losses due to cannibalistic $\left(a_{x x}\right)$ grazing were included and formulated in an analogous way to grazing on other components.

Dissolved organic carbon (DOC) equation

(Table 2, Eq. T8): DOC is produced as a byproduct of autotroph growth (defined by the $4 \phi_{x y}$ terms). The remaining terms represent production of DOC during grazing ('sloppy feeding') and the breakdown of detritus. DOC is taken up by the bacteria.

Detritus equation (Table 2, Eq. T11): Detritus $\left(D_{T}\right)$ is produced in the course of grazing by heteroflagellates $\left(a_{t h c} P_{C}, a_{t h b} B\right.$, and $\left.a_{t h h} H_{f}\right)$ and larger microzooplankton $\left(a_{t z p} P_{d}, a_{t z n} P_{n}, a_{t z f} P_{f}, a_{t z h} H_{f}, a_{t z t} D_{t}\right.$, and $\left.a_{t z z} Z\right)$. See the legend to Table 2 for the definitino of $a_{X}$ terms. Detritus concentrations decrease through grazing by heteroflagellates $\left(a_{t h} D_{t}\right)$ and breakdown by attached heterotrophic bacteria $\left(m_{t t}\right)$.

All respiration rates were temperature-dependent following the equations of Taylor et al. (1993).

Table 2. Main biological interactions within Taylor Monod Model-1 and Model-2 (TMM-1 and TMM-2). Each coefficient $a_{X}$ describes a rate of transfer between state variables. Thus, $a_{d h b}$ is the constant representing the rate of dissolved organic carbon $(d)$ production resulting from heteroflagellates $(h)$ grazing bacteria $(b)$. The subscripts associated with the other state variables are diatoms $(p)$, dinoflagellates $(n)$ phytoflagellates $(f)$, picophytoplankton $(c)$, larger microzooplankton $(z)$, silicate $(S)$, nitrate $(N)$, ammonium $(A)$ and detritus $(t)$. In the same way, each coefficient $m_{x}$ is a loss associated with the natural mortality (there being no loss but to mesograzer mortality as these organisms had been excluded from the experiments). For definitions of terms see 'Materials and methods'; fuller explanation is given in Taylor et al. (1993)

$$
\begin{aligned}
\mathrm{d} P_{d} / \mathrm{d} t= & \left(a_{p} \phi_{p}-m_{p}-k\right) P_{d} \\
\mathrm{~d} P_{n} / \mathrm{d} t= & \left(a_{n} \phi_{N A n}-m_{n}-k\right) P_{n} \\
\mathrm{~d} P_{f} / \mathrm{d} t= & \left(a_{f} \phi_{N A f}-m_{f}-a_{f z} Z-k\right) P_{f} \\
\mathrm{~d} P_{c} / \mathrm{d} t= & \left(a_{c} \phi_{N A c}-m_{c}-a_{c h} H_{f}-k\right) P_{c} \\
\mathrm{~d} B / \mathrm{d} t= & \left(a_{b} \phi_{d}-m_{b}-a_{b h} H_{f}-k\right) B \\
\mathrm{~d} H_{f} / \mathrm{d} t= & \left(a_{h c} P_{c}+a_{h b} B+a_{h t} D_{T}-m_{h}-a_{h h} H_{f}-a_{h z} Z-k\right) H_{f} \\
\mathrm{~d} Z / \mathrm{d} t= & \left(a_{z f} P_{f}+a_{z h} H_{f}+a_{z t} D_{T}-m_{z}-a_{z z} Z-k\right) Z \\
\mathrm{~d} D / \mathrm{d} t= & \left(a_{d p} \phi_{p}+m_{d p}\right) P_{d}+\left(a_{d n} \phi_{N A}+m_{d n}\right) P_{n}+\left(a_{d f} \phi_{N A}+m_{d f}\right) P_{f}+\left(a_{d c} \phi_{N A}+m_{d c}\right) P_{c}-a_{d b} \phi_{d} B+m_{d h} H_{f}+m_{d z} Z \\
& \quad+\left(a_{d z f} P_{f}+a_{d z h} H_{f}+a_{d z t} D_{T}+a_{d z z} Z\right) Z+\left(a_{d h c} P_{c}+a_{d h b} B+a_{d h t} D_{T}+a_{d h h} H_{f}\right) H_{f}+m_{d t} D_{T}+m_{d b} B+\left(D_{0}-D\right) k \\
\mathrm{~d} N / \mathrm{d} t= & \left(N_{0}-N\right) k-\left(a_{n p} \phi_{p} \phi_{N r} P_{d}+a_{N A n} \phi_{N} P_{n}+a_{N A f} \phi_{N} P_{f}+a_{N A c} \phi_{N} P_{c}+a_{N d b} \phi_{N} B\right) \\
\mathrm{d} A / \mathrm{d} t= & \left(A_{0}-A\right) k-\left(a_{A p} \phi_{p} \phi_{A r} P_{d}+a_{N A n} \phi_{A} P_{n}+a_{N A f} \phi_{A} P_{f}+a_{N A c} \phi_{A} P_{c}+a_{A d b} \phi_{d} B\right) \\
& \quad+m_{A p} P_{d}+m_{A n} P_{n}+m_{A f} P_{f}+m_{A c} P_{c}+m_{A h} H_{f}+m_{A z} Z+m_{A t} D_{t}+m_{A b} B \\
\mathrm{~d} D_{T} / \mathrm{d} t= & m_{t p} P_{d}+m_{t n} P_{n}+m_{t c} P_{c}+m_{t h} H_{f}+m_{t z} Z+m_{t b} B-m_{t t} D_{t}+\left(a_{t h c} P_{C}+a_{t h b} B-\left(a_{t h}-a_{t h t}\right) D_{T}+a_{t h h} H_{f}\right) H_{f} \\
& +\left(a_{t z p} P_{d}+a_{t z n} P_{n}+a_{t z f} P_{f}+a_{t z h} H_{f}+a_{t z t} D_{T}+a_{t z z} Z\right) Z \\
\mathrm{Model} \mathrm{TMM-2} \mathrm{only:} & \\
\mathrm{d} S / \mathrm{d} t= & \left(S_{0}-S\right) k-a_{s p} \phi_{p} P_{d}
\end{aligned}
$$


We next outline the 3 versions of the biological model for autotrophs that were studied comparatively.

Biological Model 1: Single-nutrient Monod kinetics, TMM-1. Our first model is identical in format to that of Taylor et al. (1993). The model assumes a single inorganic nutrient $(\mathrm{N})$, as either nitrate or ammonia and limits the growth of all autotrophic groups. (Henceforth this model is referred to as the Taylor Monod Model-1, TMM-1). The model employs Monod-style kinetics to represent autotroph $\left(P_{d}, P_{n}, P_{f}, P_{c}\right)$ growth on this nutrient, i.e. the rate of $C$ biomass growth is a function of extracellular rather than intracellular nutrient concentration; $\mathrm{C}$ biomass increase is related to nutrient uptake by a constant yield. The full set of equations describing TMM-1 are included in Table 2. This model was formulated with the specific intention of minimising the physiological differences between the autotrophic phytoplankton populations included in the simulation. The phytoplankton groups therefore differ only in their growth rates and their trophic relationships.

Autotroph growth (Table 2, Eqs. T1-T4): The growth rate of autotrophs, is defined by the maximum growth rate and the influence of both light and nutrient limitation, following an equation of the form

$$
a_{X} \phi_{X}
$$

The term $a_{x}$ represents maximum growth rate $\left(\mu_{\text {max } \_x}\right)$ of organism $x$, and a hyperbolic function $(I)$ that accounts for the influence of light limitation (this latter function is more fully defined in Taylor et al. 1993) Hence:

$$
a_{x}=\mu_{\text {max } \_x} I
$$

The term $\phi_{X}$ represents the influence of nutrient limitation. Autotrophs are assumed to be able to utilise both nitrate, $N$, and ammonia, $A$, with nutrient limitation of growth rate expressed by:

$$
\phi_{X}=\phi_{N A X}=\phi_{N X}+\phi_{A x}
$$

where:

$$
\begin{aligned}
\phi_{N x} & =\left(N / N_{h x}\right) /\left(1+N / N_{h x}+A / A_{h x}\right) \\
\phi_{A x} & =\left(A / A_{h x}\right) /\left(1+N / N_{h x}+A / A_{h x}\right)
\end{aligned}
$$

where $x$ defines the appropriate autotroph group: diatoms $(p)$, dinoflagellates $(n)$, phytoflagellates $(f)$ and picophytoplankton $(c) . \quad N_{h x}$ and $A_{h x}$ are the halfsaturation constants for nitrate and ammonium uptake. The value of $A_{h x}$ and $N_{h x}$ were initially set to the same value for all autotroph groups (Table 3 ).

Inorganic nutrients. Equations for nitrate and ammonium uptake were as follows:

Nitrate equation (Table 2, Eq. T9): Nitrate concentrations change through uptake by the 4 groups of autotrophic phytoplankton $\left(a_{N p} \phi_{p} \phi_{N r}, a_{N A n} \phi_{N}, a_{N A f} \phi_{N}\right.$, and $\left.a_{N A c} \phi_{N}\right)$ and by bacteria $\left(a_{N d b} \phi_{N}\right)$, and water renewal $(k)$.

Ammonium equation (Table 2, Eq. T10): Uptake of ammonium by the 4 groups of autotrophs $\left(a_{A p} \phi \phi_{A}\right.$, $a_{N A i} \phi_{A}, a_{N A f} \phi_{A}$, and $\left.a_{N A c} \phi_{A}\right)$ and by bacteria $\left(a_{A d b} \phi_{d}\right)$ are treated analogously to the nitrate equation as are changes due to water renewal $(k)$. The remaining terms $\left(m_{A p}, m_{A i}, m_{A f}, m_{A c}, m_{A h}, m_{A z}, m_{A t}\right.$, and $\left.m_{A b}\right)$ represent the excretion of ammonium associated with respiration by diatoms, dinoflagellates, phytoflagellates, picophytoplankton, heteroflagellates, larger microzooplankton, detritus, and bacteria respectively.

\begin{tabular}{|c|c|c|c|c|c|c|}
\hline Name & TMM parameter & & Units & $\begin{array}{l}\text { Original } \\
\text { values }\end{array}$ & $\begin{array}{c}\text { Tuned } \\
\text { TMM-1 }\end{array}$ & $\begin{array}{c}\text { Tuned } \\
\text { TMM-2 }\end{array}$ \\
\hline$\mu_{\max \_d} d$ & \multirow[t]{4}{*}{ Maximum specific growth rate of: } & Diatoms & \multirow[t]{4}{*}{$\mathrm{d}^{-1}$} & 0.9 & 1.0 & 1.2 \\
\hline$\mu_{\text {max } \_n}$ & & Dinoflagellates & & 0.3 & 0.5 & 0.5 \\
\hline$\mu_{\text {max_f }}$ & & Phytoflagellates & & 1.5 & 1.7 & 1.2 \\
\hline$\mu_{\text {max } \mathrm{c}}$ & & Picophytoplankton & & 1.5 & 2.0 & 1.3 \\
\hline$N_{h d}$ & \multirow[t]{4}{*}{ Nitrate half-saturation constant of: } & Diatoms & $\mathrm{mmol} \mathrm{m}^{-3}$ & 0.3 & 0.1 & 0.4 \\
\hline$N_{h n}$ & & Dinoflagellates & & & 0.3 & 0.5 \\
\hline$N_{h f}$ & & Phytoflagellates & & & 0.5 & 0.5 \\
\hline$N_{h c}$ & & Picophytoplankton & & & 0.7 & 0.3 \\
\hline $\mathrm{A}_{h d}$ & \multirow[t]{4}{*}{ Ammonia half-saturation constant of: } & Diatoms & $\mathrm{mmol} \mathrm{m}{ }^{-3} 5$ & $5 \times 10^{-3}$ & $1 \times 10^{-2}$ & $7 \times 10^{-3}$ \\
\hline $\mathrm{A}_{h n}$ & & Dinoflagellates & & & $6 \times 10^{-3}$ & $4 \times 10^{-3}$ \\
\hline $\mathrm{A}_{h f}$ & & Phytoflagellates & & & $9 \times 10^{-3}$ & $4 \times 10^{-3}$ \\
\hline $\mathrm{A}_{h c}$ & & Picophytoplankton & & & $4 \times 10^{-3}$ & $4 \times 10^{-3}$ \\
\hline Cil & \multicolumn{2}{|l|}{$\begin{array}{l}\text { Ratio of grazing rates of larger micro- } \\
\text { zooplankton to heteroflagellates }\end{array}$} & Dimensionless & s $\quad 0.3$ & 0.11 & 0.18 \\
\hline Gams & \multicolumn{2}{|l|}{ Carbon yield per unit Si } & $\mathrm{mg} \mathrm{C} \mathrm{mg} \mathrm{Si} \mathrm{m}^{-1}$ & 28 & 4.25 & 4.05 \\
\hline$S_{h}$ & \multicolumn{2}{|l|}{ Silicate half-saturation constant } & $\mathrm{mmol} \mathrm{m} \mathrm{m}^{-3}$ & 0.3 & - & 0.25 \\
\hline
\end{tabular}
For a more complete description of the interactions described within these nitrate and ammonium equations refer to Taylor et al. (1993).

Table 3. TMM parameter values. Original parameter values were taken from Taylor et al. (1993) 
Biological Model 2: Dual-nutrient Monod kinetics, TMM-2. Our second version of the biological model includes a second nutrient, Si. Nutrient uptake and nutrient-limited growth by dinoflagellates, phytoflagellates and picoflagellates is modelled in an identical manner to TMM-1, utilising only N. However, diatoms now take up both $\mathrm{N}$ and $\mathrm{Si}$, with growth limited by the nutrient in least relative supply. This 2-nutrient, threshold style model will be referred to as the Taylor Monod Model-2 (TMM-2) it is represented schematically in Figs. 2 \& 3.

The nutrient limitation of Si-limited diatom growth is governed by the relation:

$$
\phi_{S p}=S /\left(S+S_{h}\right)
$$

where $S$ is the $\mathrm{Si}$ concentration and $S_{h}$ is the halfsaturation constant for Si uptake.

For TMM-2, the nutrient limitation of diatom growth, $\phi_{p}$ (Eq. T1, Table 2), is therefore defined by: tures of diatom growth observed in the experiments of Davidson et al. (1999), i.e. finite threshold Si concentrations and observed reduced growth rates when both $\mathrm{N}$ and Si concentrations were low, it was necessary to derive and employ a modified version of the cell quota model, the co-nutrient model. Davidson \& Gurney (1999) parameterised the model using cell numbers as an index of biomass, but noted that using an identical structure the model was also capable of simulating $\mathrm{C}$ biomass. Here we have parameterised the co-nutrient model structure to simulate $\mathrm{C}$ biomass of diatoms, dinoflagellates and phytoflagellates. This quota-style model will henceforth be referred to as the Davidson Taylor Quota Model (DTQM); it is represented schematically in Figs. $2 \& 3$. The set of equations describing the DTQM within the biological model are outlined in Table 4. Parameter values based on cell numbers and taken from Davidson \& Gurney (1999) or elsewhere were converted to $\mathrm{C}$ biomass-specific val-

$$
\phi_{P}=\min \left\{\begin{array}{l}
\phi_{S p} \\
\phi_{N A p}
\end{array}\right.
$$

The rate of change of inorganic $\mathrm{Si}$ in TMM-2 is described by Eq. (T12). Si concentrations are governed by diatom uptake and water renewal.

Within the $a_{p}$ term of the model, a further parameter (Gams; Table 3), defines the yield of particulate $\mathrm{C}$ per unit of silicate taken up under Silimited conditions.

Biological Model 3: Quota-based growth functions, Davidson Taylor Quota Model (DTMQ). In this third version of the model we choose to introduce quota (Caperon 1968, Droop 1968)-based growth functions for 3 of the 4 autotrophic groups, namely diatoms, dinoflagellates and phytoflagellates (Table 4, with parameter values presented in Table 5). Nutrient uptake occurs as a rectangular hyperbolic function of extracellular nutrient concentration moderated by a feedback mechanism related to intracellular nutrient:C (the cell quota, $Q$ ) preventing abnormally high intracellular nutrient:C ratios. The specific rate of biomass increase is then calculated using a rectangular hyperbolic function of the ratio of $Q$ above a minimum threshold $\left(Q_{0}\right)$.

Previously, Davidson \& Gurney (1999) found that to simulate the fea-
Table 4. Davidson Taylor Quota Model (DTQM) equations. DTQM model uses Eqs. (T4) to (T8) and (T11) from Table 2 together with Eqs. (T13) to (T24) from this table. Eqs. (T1) to (T3), (T9) to (T10) and (T12) from Table 2 are replaced with (T13) to (T18). For detailed explanation of the underpinning rationale of the co-nutrient model see Davidson \& Gurney (1999)

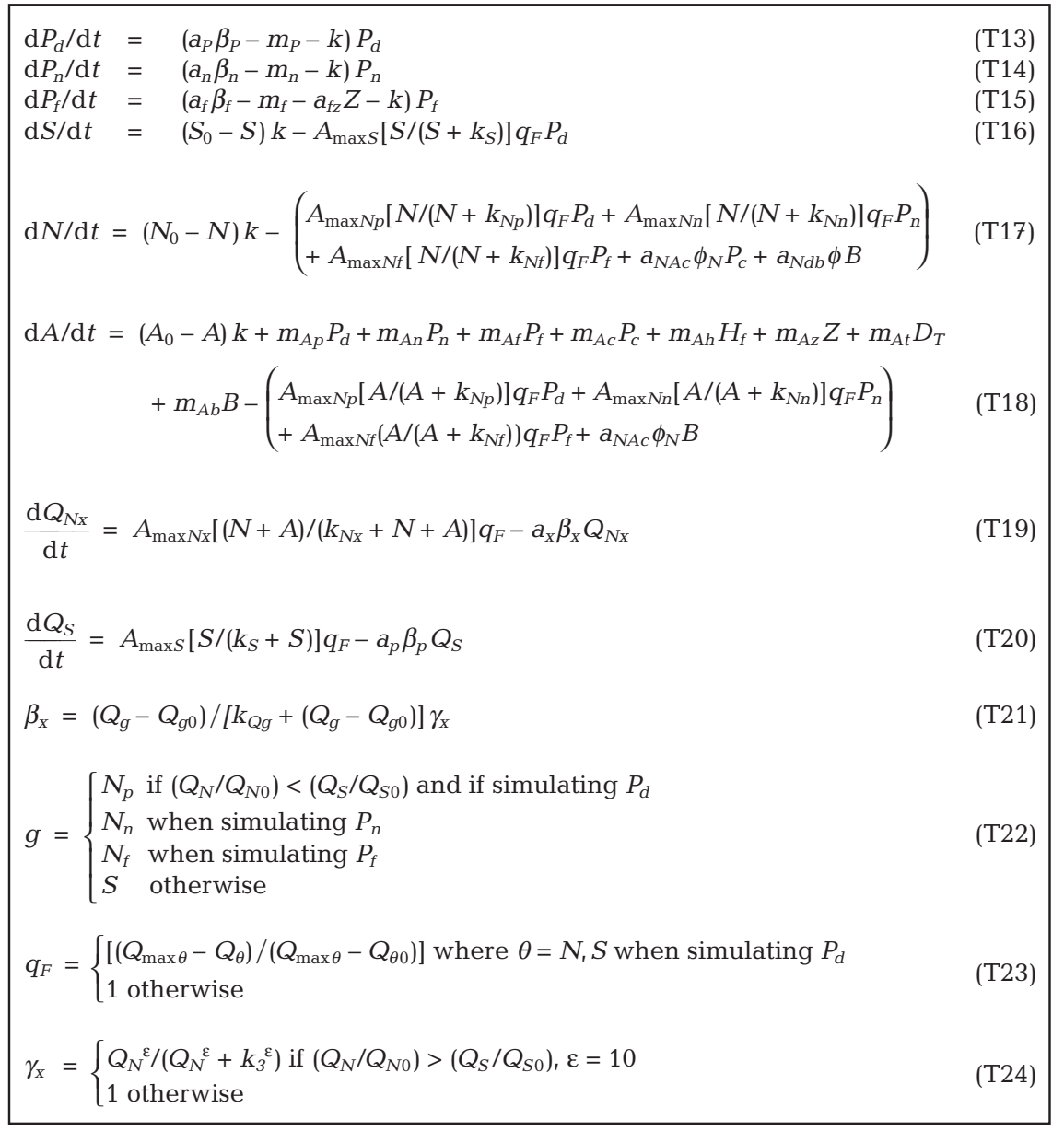





Fig. 2. Schematic diagram of format of the diatom model within (a) Taylor Monod Model-2 (TMM-2) and (b) Davidson Taylor Quota Model (DTQM)

ues using the experimentally observed values of carbon per cell for each functional group (Davidson et al. 2002) from our mesocosms. The functional behaviour of equations of particular interest to our study are described below for a single organism, assuming 2 potentially limiting nutrients $\mathrm{N}$ and $\mathrm{Si}$.

The rate of nutrient uptake is governed by a rectangular hyperbolic function of the extracellular nutrient concentration:

$$
A_{\max Z}\left(\frac{Z}{Z+k_{z}}\right) q_{F}
$$

where $A_{\max Z}$ is the maximum uptake of $Z$, where $Z=$ $N, S$ and $k_{Z}$ is the half-saturation constant.

$q_{F}$ (Eqs. $8 \&$ T23) is a feedback mechanism preventing abnormally high intracellular nutrient:C ratios:

$$
q_{F}=\left(\frac{Q_{\max \theta}-Q_{\theta}}{Q_{\max \theta}-Q_{\theta 0}}\right)
$$

where $Q_{\theta}$ is the cell quota per unit C $(\theta=N$ or $S)$, minimum $Q_{\theta 0}$, maximum $Q_{\text {max_}_{-} \text {. }}$.

The influence of nutrient limitation on growth rate is governed (Eq. T21) by a parameter $\beta$ related to the internal cell quota and $\gamma$ (the degree of reduction in growth rate due to low concentrations of a non-limiting nutrient, see Eq. 13 below):

$$
\beta=\left(Q_{g}-Q_{g 0}\right) /\left[k_{Q g}+\left(Q_{g}-Q_{g 0}\right)\right] \gamma
$$

where $k_{Q g}$ is the half-saturation constant.

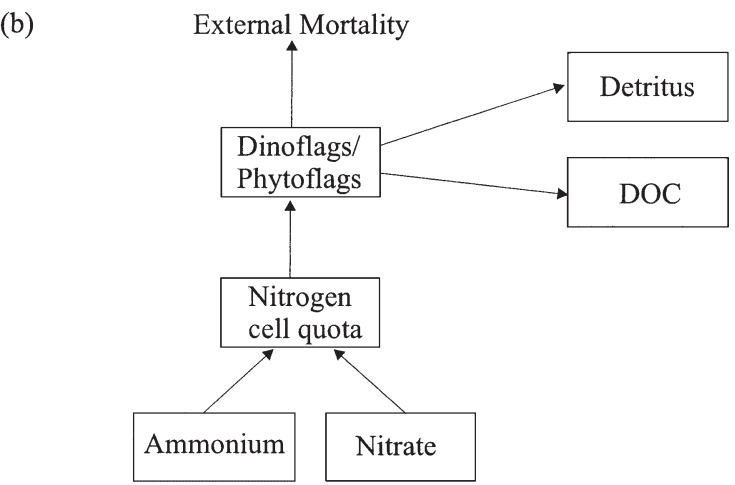

Fig. 3. Schematic diagram of format of autotrophic dinoflagellates and phytoflagellates within (a) Taylor Monad Model-2

(TMM-2) and (b) Davidson Taylor Quota Model (DTQM)

$g$ (Eqs. 10 \& T22) defines the limiting nutrient and is defined by

$$
g=\left\{\begin{array}{l}
N \text { if }\left(Q_{N} / Q_{N 0}\right)<\left(Q_{S} / Q_{S 0}\right) \\
S \text { otherwise }
\end{array}\right.
$$

The rate of growth of an organism (Eqs. T13 to T15) is therefore defined by:

$$
a_{X} \beta
$$

where, as for Models TMM-1 and TMM-2, the term $a_{x}$ defines the maximum growth rate and the influence of light limitation.

$\gamma_{1}$ the degree of reduction in uptake and growth rate due to low concentrations of a non-limiting nutrient, is defined (Eq. T24) as

$$
\gamma=\left\{\begin{array}{l}
{Q_{N}}^{\varepsilon} /\left({Q_{N}}^{\varepsilon}+k_{3}^{\varepsilon}\right) \text { if }\left(Q_{N} / Q_{N 0}\right)>\left(Q_{S} / Q_{S 0}\right) \\
1 \text { otherwise }
\end{array}\right.
$$

where $\varepsilon$ is a shape parameter that determines the degree of inflection of the curve and $k_{3}$ is analogous to the half-saturation constant in a Michaelis-Menten hyperbola.

Finally, to prevent unreasonably large luxury storage of Si when diatoms are $\mathrm{N}$-limited we relate $Q_{\text {max_S }}$ to $Q_{N}$ thus:

$$
Q_{\max S}=Y \cdot Q_{N}
$$

where $Y$ is a constant. 
Table 5. DTQM parameter values. Baseline values (not shown) around which tuning was conducted were taken or estimated from Conway et al. (1976), Davidson \& Gurney (1999), Paasche (1973), and Taylor et al. (1993)

\begin{tabular}{|c|c|c|c|c|}
\hline Name & DTQM Parameter & & Units & Tuned values \\
\hline$A_{\max S}$ & Maximum diatom uptake rate of $\mathrm{Si} \mathrm{d}^{-1}$ & & $\mathrm{mgSi} \mathrm{mgC} \mathrm{C}^{-1} \mathrm{~d}^{-1}$ & 0.41 \\
\hline$A_{\max N p}$ & Maximum uptake rate of $\mathrm{N} \mathrm{d}^{-1}$ of: & Diatoms & 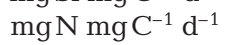 & 0.21 \\
\hline$A_{\max N n}$ & & Dinoflagellates & $\operatorname{mgN} \mathrm{mgC}^{-1} \mathrm{~d}^{-1}$ & 0.10 \\
\hline$A_{\max N f}$ & & Phytoflagellates & $\mathrm{mgN} \mathrm{mgC}^{-1} \mathrm{~d}^{-1}$ & 0.06 \\
\hline$k_{S}$ & half-saturation constant for diatom Si uptake: & & mmol Si m ${ }^{-3}$ & 0.8 \\
\hline$k_{N p}$ & Half-saturation constant for N uptake: & Diatoms & $\mathrm{mmol} \mathrm{N} \mathrm{m}^{-3}$ & 0.3 \\
\hline$k_{N n}$ & & Dinoflagellates & $\mathrm{mmol} \mathrm{N} \mathrm{m}^{-3}$ & 0.4 \\
\hline$k_{N f}$ & & Phytoflagellates & $\mathrm{mmol} \mathrm{N} \mathrm{m}^{-3}$ & 0.4 \\
\hline $\mathrm{N}_{h c}$ & & Picophytoplankton & $\operatorname{mmol~} \mathrm{N} \mathrm{m}^{-3}$ & 0.2 \\
\hline$\mu_{\text {max } \_d}$ & Maximum specific growth rate of: & Diatoms & $\mathrm{d}^{-1}$ & 1.4 \\
\hline$\mu_{\max \_n}$ & & Dinoflagellates & $d^{-1}$ & 0.3 \\
\hline$\mu_{\max _{-} f}$ & & Phytoflagellates & $\mathrm{d}^{-1}$ & 0.9 \\
\hline$\mu_{\text {max } \_c}$ & & Picophytoplankton & $\mathrm{d}^{-1}$ & 1.8 \\
\hline$k_{Q S}$ & Half-saturation constant for growth: & Diatoms (Si is yield-limiting) & $\mathrm{mgSi} \mathrm{mg} \mathrm{C}^{-1}$ & 0.3 \\
\hline$k_{Q N p}$ & & Diatoms (N is yield-limiting) & $\mathrm{mgN} \mathrm{mgC}^{-1}$ & 0.4 \\
\hline$k_{Q n n}$ & & Dinoflagellates & $\mathrm{mgN} \mathrm{mgC}^{-1}$ & 0.2 \\
\hline$k_{Q N f}$ & & Phytoflagellate & $\mathrm{mgN} \mathrm{mgC}^{-1}$ & 0.1 \\
\hline$Q_{S 0}$ & Minimum cell quota for: & Diatom Si & $\mathrm{mgSi} \mathrm{mg} \mathrm{C}^{-1}$ & 0.04 \\
\hline$Q_{N p 0}$ & & Diatom N & $\mathrm{mgN} \mathrm{mg} \mathrm{C}^{-1}$ & 0.12 \\
\hline$Q_{N n 0}$ & & Dinoflagellate $\mathrm{N}$ & $\mathrm{mgN} \mathrm{mg} \mathrm{C}^{-1}$ & 0.04 \\
\hline$Q_{N f 0}$ & & Phytoflagellate $\mathrm{N}$ & $\mathrm{mgN} \mathrm{mgC}^{-1}$ & 0.10 \\
\hline$Q_{\max S}$ & Maximum cell quota for: & Diatom $\mathrm{Si}$ & $\mathrm{mgSi} \mathrm{mg} \mathrm{C}^{-1}$ & $5 \times Q_{N}$ \\
\hline$Q_{\max N}$ & & Diatom N & $\mathrm{mgN} \operatorname{mg} \mathrm{C}^{-1}$ & 2.4 \\
\hline$k_{3}$ & Half-saturation constant in function $\gamma$ & & $\mathrm{mg} \mathrm{N} \mathrm{mgCC}^{-1}$ & 0.62 \\
\hline
\end{tabular}

When simulating dinoflagellates and phytoflagellates we need only consider 1 nutrient, $N$. Hence $Z=$ $N$ and $\gamma=1$, reducing the co-nutrient model to a standard cell-quota formulation for these groups. The DTQM model presented here is identical to that presented by Davidson \& Gurney (1999) with the following modifications: the use of $\mathrm{C}$ rather than cell numbers as the index of biomass (as discussed above), the inclusion of light limitation as a multiplicative term within Eq. (12), and the non-inclusion of $\gamma$ in uptake Eq. (8), so that only growth (Eq. 10) rather than uptake and growth is moderated by the lack of a nonlimiting nutrient.

\section{RESULTS}

In all the following simulations, models are compared with the mean data from the 4 mesocosms in each set of N:Si conditions. Comparison between model and experiment was made for the following parameters: nitrate, silicate, diatoms, phytoflagellates, dinoflagellates, heteroflagellates and larger microzooplankton. Initial conditions in the model simulations were estimated from the mean of the experimental data at time zero.

In both of the nutrient regimes studied, the microbial biomass was dominated by a bloom of diatoms, pre- dominately Skeletonema costatum. Subsequent to the peak of the diatom bloom, an increase in other microbial groups was noted.

Mesocosms ran in parallel and therefore received an identical light field. Light was therefore treated identically, in terms of model structure and parameterisation in all simulations, allowing us to compare the influence of nutrient regime.

\section{Model TMM-1}

This model employed Monod-style growth kinetics and a single potentially yield-limiting nutrient $(\mathrm{N})$ for all autotroph groups. The diatoms therefore do not utilise $\mathrm{Si}$ and are yield-limited only by the exhaustion of extracellular $\mathrm{N}$ in both sets of simulations (high and low N:Si). Initially we parameterised the model using the parameter set of Taylor et al. (1993) (Table 3). Data and model are compared (symbols and dashed lines respectively) in Fig. 4 (high N:Si mesocosms) and Fig. 5 (low N:Si mesocosms) respectively.

In both simulations the model qualitatively predicted the uptake of extracellular $\mathrm{N}$, with $\mathrm{N}$ exhaustion being predicted within $2 \mathrm{~d}$ of that observed in both N:Si conditions. In both cases the model predicted an approximately exponential increase of diatom $\mathrm{C}$ biomass when $\mathrm{N}$ concentrations remained greater than zero. $\mathrm{A}$ 
failure of the model was that, subsequent to $\mathrm{N}$ exhaustion, the diatom biomass was predicted to continue increasing in a linear fashion and hence to overestimate the observed values. This increase was related to the $\mathrm{N}$ supplied within the renewal water.

The model also significantly overpredicted the observed phytoflagellate biomass. A large peak of phytoflagellates was predicted, approximately 10 and 15 times that observed, at the same time-point in high and low N:Si mesocosms respectively. This peak decreased rapidly through grazing by heterotrophs and washout following the depletion of N. In contrast, the simulation of autotrophic dinoflagellates was relatively good in terms of $\mathrm{C}$ biomass. However, the model predicted a decrease in dinoflagellate biomass subsequent to $\mathrm{N}$ exhaustion in both nutrient regimes, contrary to the observed increase.

The simulation of heterotrophic flagellates showed a slow increase throughout. The model failed to predict the decrease in heteroflagellate biomass near the end of the experiments. Larger microzooplankton biomass was significantly overpredicted by the model, showing a peak of 120 to 50 times that observed at the same time point in high and low N:Si conditions respectively, and a subsequent decrease.
In order to obtain a quantitative measure of the goodness-of-fit of the model to the data sets, 2 alternative measures were used. Correlation coefficients and weighted mean-square residuals were calculated between the model output and the mean observed data for each output parameter. As we wished to determine the overall fit of each version of the model (using a single parameter set) to the complete data set, we pooled the results from the 2 scenarios (high and low $\mathrm{N}$ :Si data) for each variable when conducting these calculations for correlation and mean-squared residuals. The correlation coefficients and mean-squared residuals for Model TMM-1 are presented in Tables 6 \& 7 respectively. For correlation, a low mean value of 0.37 was obtained. Indeed only heterotrophic flagellates and nitrate showed significant correlation between model and experiment at the 95\% level. The mean-squared residual values were high, also indicating a poor fit of the model to data. This was particularly true for larger microzooplankton, but diatoms, nitrate and phytoflagellates were also poorly simulated by the model. We therefore revised the model parameterisation by varying each of the relevant parameters of the biological model (Table 3) in turn, using a numerical optimisation programme Powersim Solver ${ }^{\circledR}$ (Version 2.0,
Fig. 4. Fit of Taylor Monod Model-1 (TMM-1) to high N:Si data $(\bullet)$ using parameters of Taylor et al. (1993) (dashed lines) and optimised parameters (continuous lines)
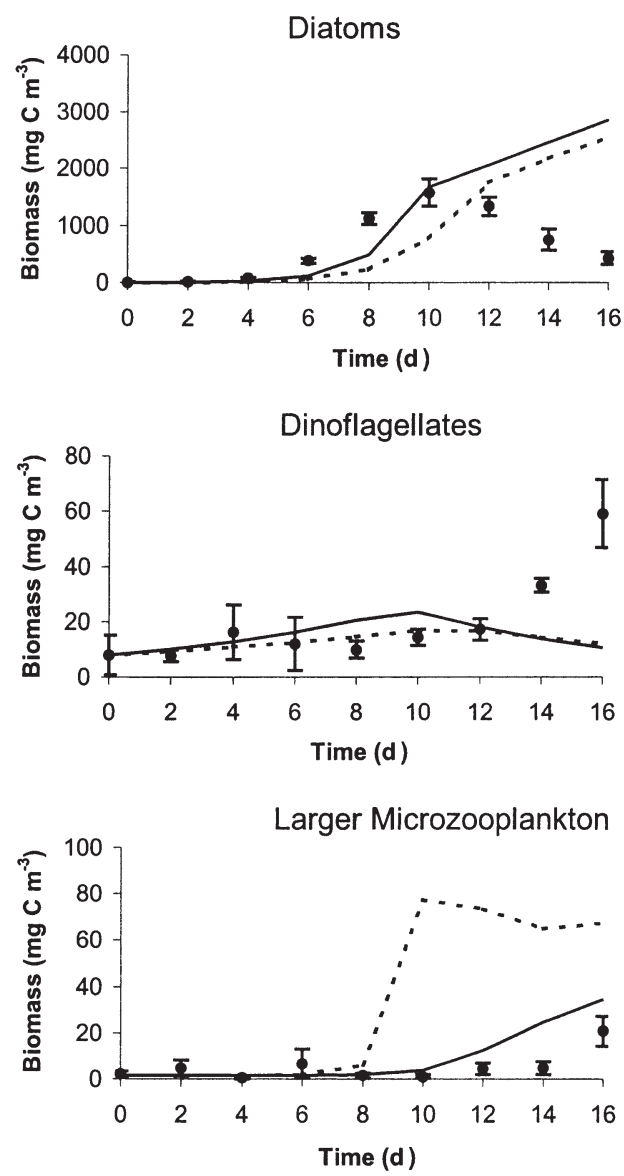
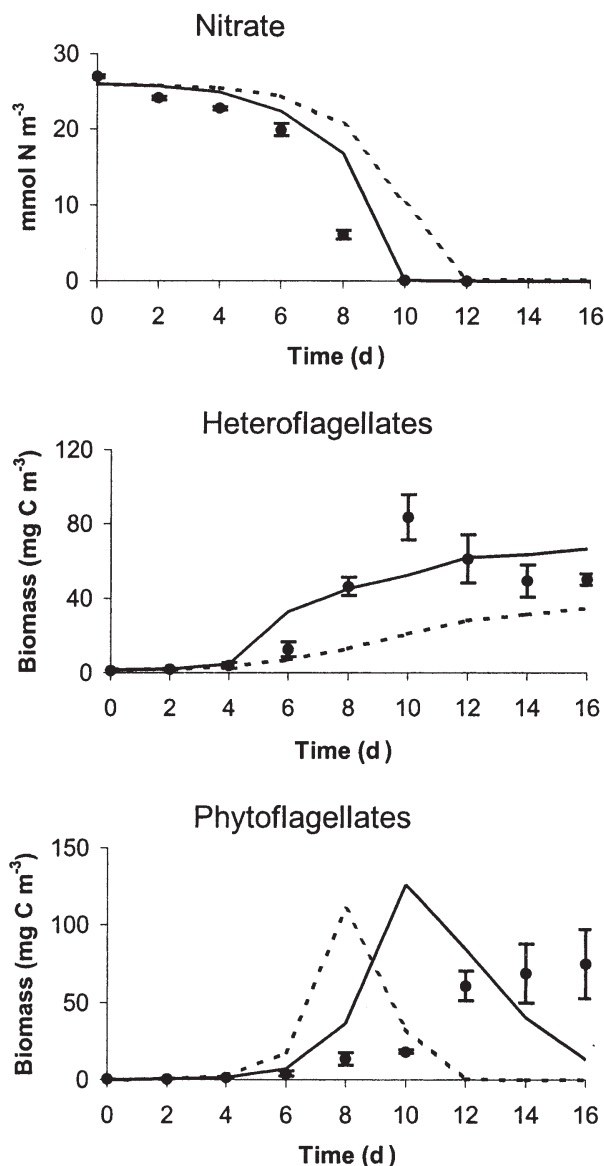

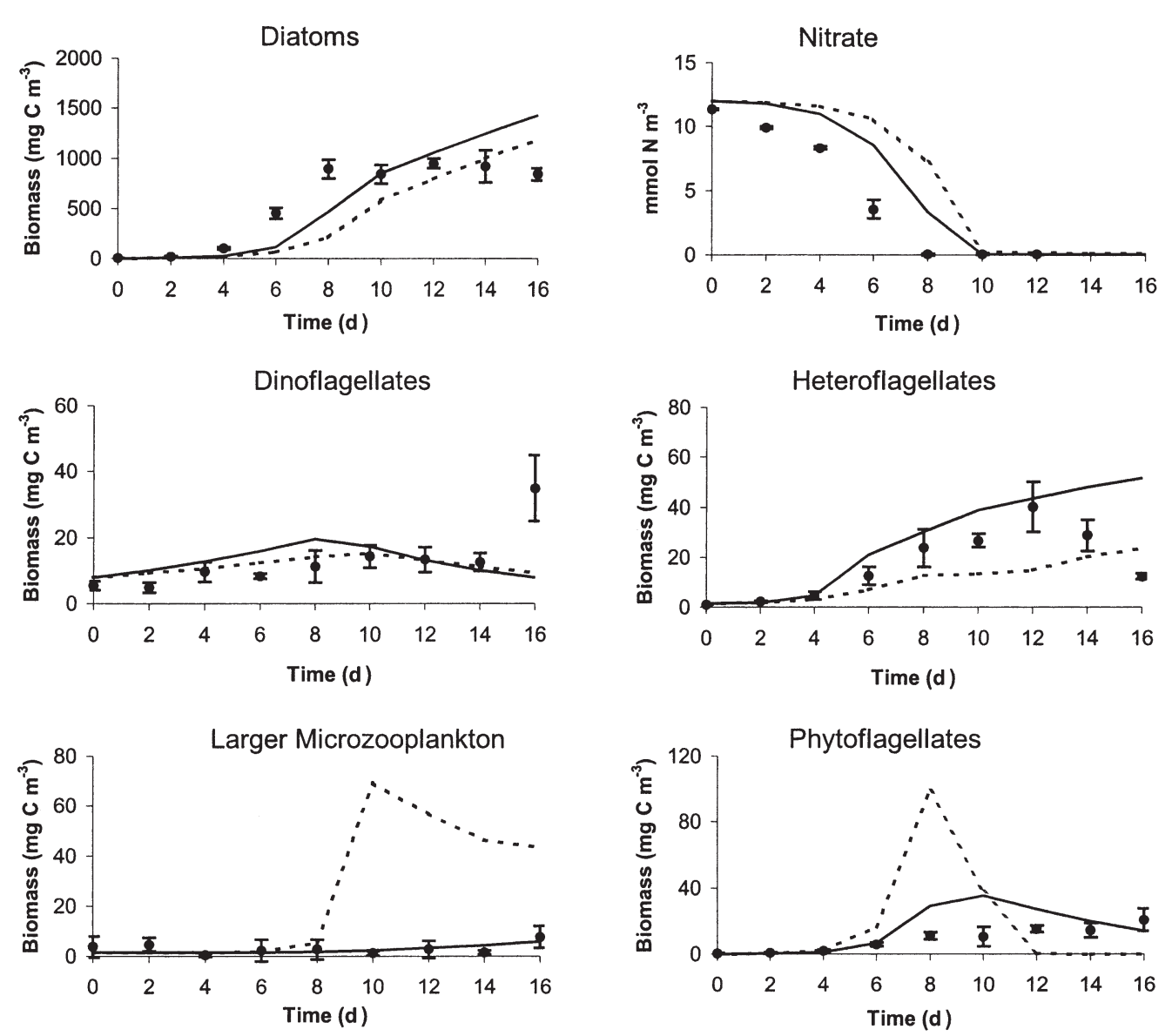

Fig. 5. Fit of Model TMM-1 to low N:Si data $(\bullet)$ using parameters of Taylor et al. (1993) (dashed lines) and revised optimised parameters (continuous lines)

Powersim AS, Norway), that applies a weighted leastsquares minimisation technique. To prevent biologically unrealistic solutions, parameters were allowed to vary only within biologically reasonable limits.

The model predictions following this re-parameterisation are presented as continuous lines in Figs. 4 (high N:Si) \& 5 (low N:Si). Calculated correlation coefficients (Table 6) reflect the improvement in simulation quality, the average value increasing from 0.37 to 0.63 , with all quantities except dinoflagellates and phytoflagellates showing a significant positive correlation between data and experiment at the $95 \%$ level. Least-squares residuals also indicated a substantial improvement in the quality of the simulation with the sum of squared residuals reducing almost 20-fold.

In spite of these changes, an obvious qualitative failing of the model was the continual increase in the predicted diatom biomass throughout the simulations, indicating that it was failing to capture the true dynamics of the system. A possible cause of this was the absence of an Si-limitation function from the model; hence Si-limitation of diatom C biomass increase could not occur.

\section{Model TMM-2}

The second version of the model included a dual nutrient currency of $\mathrm{N}$ and $\mathrm{Si}$. The diatom population was limited by the nutrient ( $\mathrm{N}$ or $\mathrm{Si}$ ) in the least relative supply as defined by Eq. (7). Comparisons between the data and Model TMM-2 are presented in Figs. 6 (high $\mathrm{N}: \mathrm{Si})$ \& 7 (low N:Si) respectively (dashed lines). The optimised parameter set of Model TMM-1 was extended to include the relevant parameter values (from Taylor et al. 1993) for Si uptake and Si-limited C biomass growth (Table 3). The model parameterisation was optimised using the Solver software as above, allowing the model to predict a larger diatom bloom in the high N:Si mesocosms and a slower consumption of inorganic Si than was otherwise predicted.

TMM-2 reproduced the observed changes in the $\mathrm{Si}$ concentration reasonably well in both sets of mesocosm conditions, however for the low N:Si conditions $\mathrm{N}$ and Si uptake was slow. An important qualitative failure of the model was the prediction of a high $\mathrm{N}$ threshold in high N:Si conditions, with net uptake of N ceasing on exhaustion of $\mathrm{Si}$. Sensitivity analysis indicated that this was a feature of this model, and not just a function of 
this particular parameterisation. Simulations of the biomass of phytoflagellates and larger microzooplankton were improved from previous versions.

The simulation of observed diatom $\mathrm{C}$ biomass were greatly improved in both nutrient regimes, with a plateau and slight decrease being predicted rather than the continual increase of TMM-1. However, the model overestimated diatom $\mathrm{C}$ in low N:Si conditions accompanied by an underestimate in the biomass of autotrophic phytoflagellates. In contrast, in high $\mathrm{N}: \mathrm{Si}$ conditions, the magnitude of predicted diatom $\mathrm{C}$ was considerably lower that the observed peak. A parameter-sensitivity analysis using both numerical and manual fitting techniques indicated that we were unable to obtain any single parameter set which cor- rectly predicted the $\mathrm{C}$ yield of diatoms in both nutrient conditions. Notwithstanding these deficiencies, the quantitative as well as qualitative indicators of simulation quality were improved using Model TMM-2. Correlation coefficients (Table 6) were considerably greater than for the previous version of the model, with an average value of 0.83 . All quantities except dinoflagellates exhibited a significant positive correlation between model and data at the $95 \%$ level. Although the sum of least-squares residuals actually increased (Table 7), this was due almost entirely to the $\mathrm{N}$ threshold predicted in high N:Si conditions (as confirmed by conducting the calculation up the point of $\mathrm{N}$ exhaustion only; Table 7). The quality of the simulation of all other quantities was found to increase using this index.

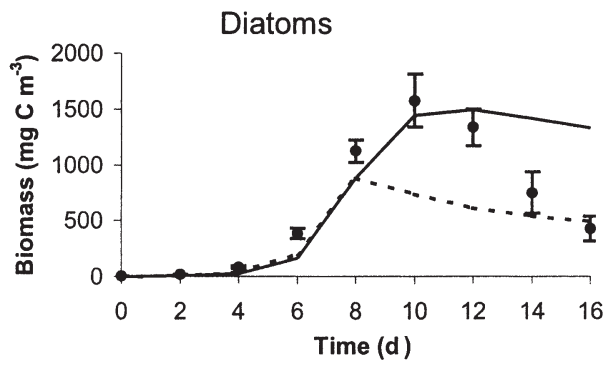

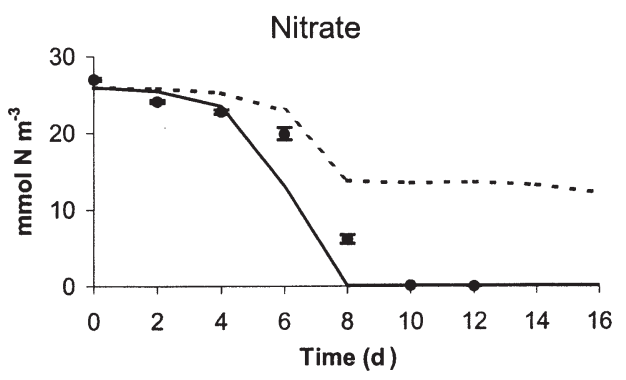
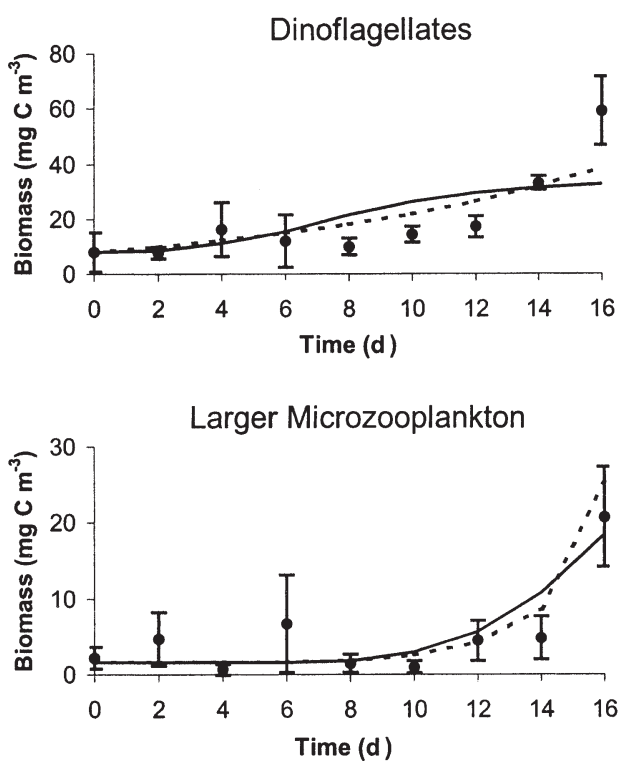
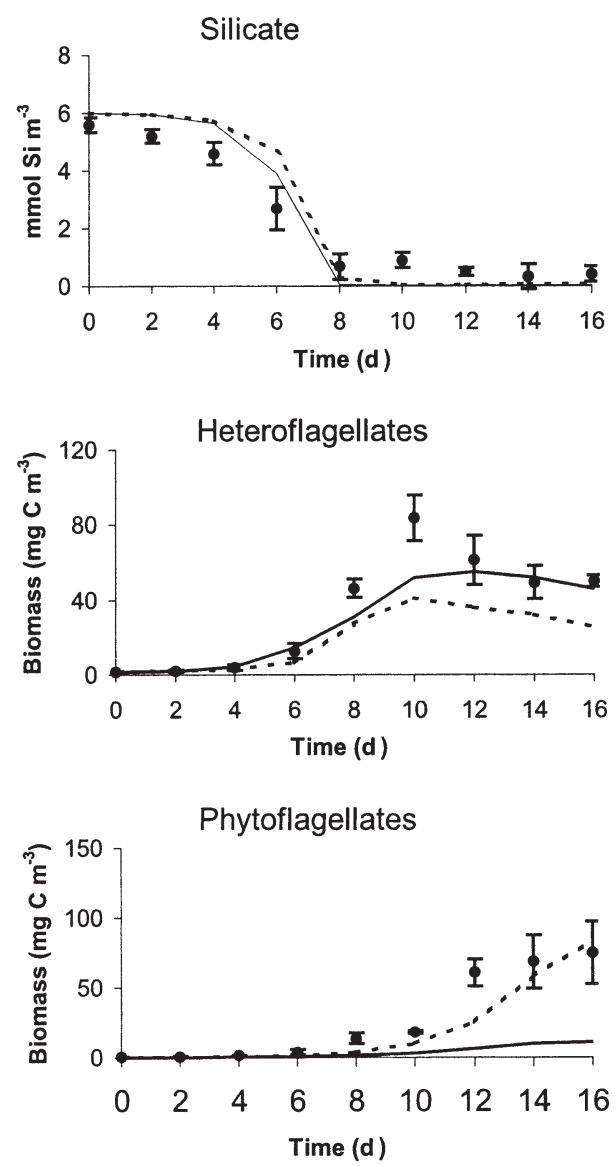

Fig. 6. Fit of Model TMM-2 (dashed lines) and DTQM (continuous lines) to high $\mathrm{N}: \mathrm{Si}$ data $(\bullet)$, both using optimised parameters 

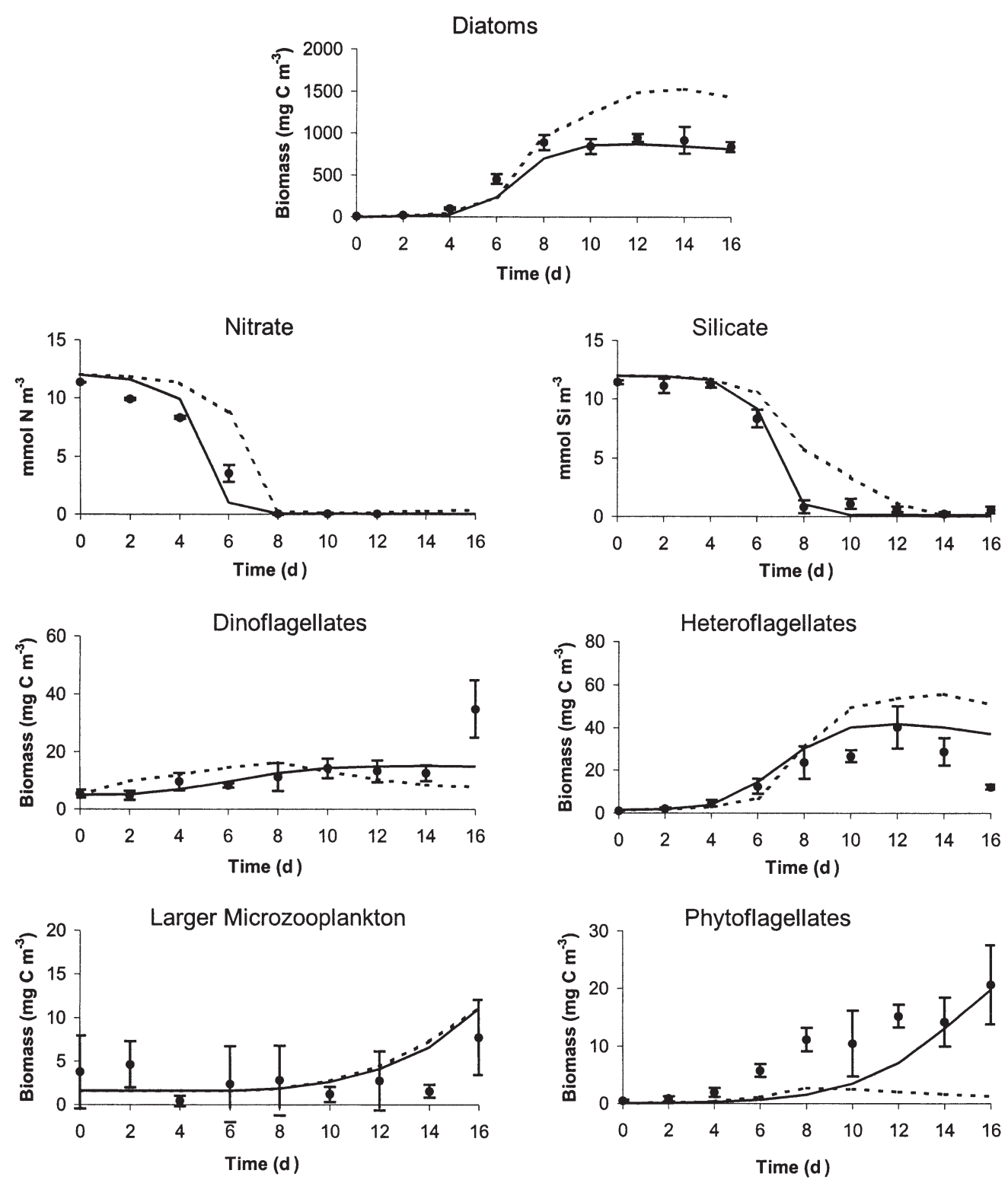

Fig. 7. Fit of Model TMM-2 (dashed lines) and DTQM (continuous lines) to the low N:Si data $(\bullet)$, both using optimised parameters

\section{Model DTQM}

The remaining deficiencies in the simulations ( $N$ threshold and inability to predict $\mathrm{C}$ biomass yield in 2 scenarios with a single parameterisation) led us to investigate the performance of the third and most physiologically complex version of the model, DTQM, in which cell quota-type formulations are applied to 3 groups of autotrophs: diatoms, dinoflagellates and phytoflagellates (Table 4; Eqs. T13 to T24). As in Model TMM-2, diatoms utilised both $\mathrm{N}$ and $\mathrm{Si}$, but now the rate of $\mathrm{C}$ biomass growth was made a function of the intracellular concentration (WRT C biomass) of the nutrient in the least relative supply.
Application of this new version of the model involved further parameterisation. Initial estimates of the parameters were obtained from literature using values within the published range for our dominant diatom Skeletonema costatum (Paasche 1973, Conway et al. 1976) and for dinoflagellates and phytoflagellates from Taylor et al. (1993) and Davidson \& Gurney (1999). Numerically tuned parameters are presented in Table 5.

Simulations are presented (lines) in Figs. 6 (high $\mathrm{N}: \mathrm{Si}$ ) \& 7 (low N:Si) respectively. Qualitatively this model performs considerably better than the previous formulations. In contrast to TMM-2 and in agreement with the data, the model predicts exhaustion of the extracellular $\mathrm{N}$ in both nutrient regimes. Peakpredicted diatom $\mathrm{C}$ is also in better agreement with 
Table 6. Pearson correlation coefficient (r) values calculated for relationship between model and combined data (both N- and Silimited) for each functional group. na: not applicable

\begin{tabular}{|lcccccccc|}
\hline & Diatoms & $\begin{array}{c}\text { Dino- } \\
\text { flagellates }\end{array}$ & $\begin{array}{c}\text { Larger micro- } \\
\text { zooplankton }\end{array}$ & $\begin{array}{c}\text { Phyto- } \\
\text { flagellates }\end{array}$ & $\begin{array}{c}\text { Hetero- } \\
\text { flagellates }\end{array}$ & Nitrate & Silicate & Ave \\
\hline TMM-1 initial parameters & 0.57 & 0.06 & 0.18 & -0.22 & 0.74 & 0.88 & na & 0.37 \\
TMM-1 fitted parameters & 0.71 & 0.23 & 0.67 & 0.48 & 0.83 & 0.95 & na & 0.63 \\
TMM-2 fitted parameters & 0.90 & 0.51 & 0.75 & 0.80 & 0.91 & 0.97 & 0.96 & 0.83 \\
DTQM fitted parameters & 0.92 & 0.67 & 0.73 & 0.93 & 0.91 & 0.98 & 0.99 & 0.87 \\
\hline
\end{tabular}

Table 7. Deviation of model from data as estimated by least-squares residuals, weighted to account for different magnitudes of the quantities within the model. Values in parentheses calculated using values only up to the time of $\mathrm{N}$ exhaustion

\begin{tabular}{|lcccccccc|}
\hline & Diatoms & $\begin{array}{c}\text { Dino- } \\
\text { flagellates }\end{array}$ & $\begin{array}{c}\text { Larger micro- } \\
\text { zooplankton }\end{array}$ & $\begin{array}{c}\text { Phyto- } \\
\text { flagellates }\end{array}$ & $\begin{array}{c}\text { Hetero- } \\
\text { flagellates }\end{array}$ & Nitrate & Silicate & Total \\
\hline TMM-1 initial parameters & 33.1 & 4.4 & 4730 & 131.2 & 10.7 & 242.5 & na & 5151.9 \\
TMM-1 fitted parameters & 41.0 & 7.9 & 64.0 & 51.8 & 47.3 & 64 & na & 276.0 \\
TMM-2 fitted parameters & 11.9 & 5.9 & 43.0 & 6.7 & 34.2 & 225.6 & 31.7 & 359.0 \\
DTQM fitted parameters & 7.8 & 4.4 & 42.5 & 7.5 & 21.8 & 35.8 & 12.5 & 132.3 \\
\hline
\end{tabular}

observations in both nutrient regimes than was achieved in the runs of earlier models, while predictions of the other variables are similar to the final run of TMM-2. The exception to this is phytoflagellate biomass, which is improved in high N:Si conditions but is significantly poorer using this model in low $\mathrm{N}: \mathrm{Si}$ conditions. However, the average correlation coefficient (Table 6) is increased from that in earlier runs, and now all quantities show a significant positive correlation between model and experiment at the 95\% level. The sum of least-squares residuals was also markedly lower (Table 7). Individual values indicated that use of the DTQM improved the fit to each quantity within the model. Hence a superior global simulation (of both nutrient regimes) with a single parameter set is achieved using the DTQM.

\section{DISCUSSION}

The critical comparison of microbial models has been hampered by difficulties in obtaining suitable test data. We therefore chose to test our models on controlled mesocosm data that had been designed to simulate a coastal ecosystem with (high N:Si) and without (low N:Si) anthropogenic $\mathrm{N}$ loading. As noted by Baretta-Bekker et al. (1998), the use of mesocosm data allows more detailed comparison between model and data to be conducted than would be possible otherwise, field data being generally patchy in terms of temporal and spatial coverage and in the parameters that have been measured and complicated by physical mixing and exchange processes.
Recently, Tett \& Wilson (2000) studied the effect of changing the number of biological functional groups within a model. Here, we have taken a complementary approach of assuming a fixed number of functional groups but varying the number of potentially limiting nutrients and the method employed to predict the specific rate of biomass growth for autotrophs (based on intracellular or extracellular nutrient concentration).

Although the sub-model of each biological group in our ecosystem model is relatively parameter-sparse, the total number of parameters within the model is quite large (over 100 parameters for DTQM). We therefore chose to explore different model formulations and parameterisations thereof by varying the parameter or parameters in question within biologically reasonable limits (set from the literature), while keeping other parameters at fixed values. Our aim was to produce the best overall fit to the combined data set (both nutrient regimes) as a whole, but in particular to focus on quantities of particular interest and importance. With the large number of parameters in the model, determining a global minimum as opposed to a local minimum while keeping all the parameters in realistic ranges is a major problem. In addition, any solution obtained may well not be unique. We have therefore used an objective numerical fitting routine, Powersim Solver ${ }^{\circledR}$, to optimise parameters, allowing us to explore the effects of changes in model structure around our initial solution based on literature parameters. To assess model performance we used 2 alternative indices, least-squares residuals and correlation. The former quantifies the sum of the magnitude of the deviation between data and model predictions at each 
data point, and the latter estimates the model's ability to follow trends in the data set.

Our initial model (TMM-1) related the rate of growth of autotrophs to extracellular N concentration. Simulations of the individual microbial groups indicate that although a qualitative representation of the early (prenutrient exhaustion) growth of diatoms, dinoflagellates and heteroflagellates could be achieved, the simulation of phytoflagellates and larger microzooplankton was poor. These model runs were parameterised using the data set published by Taylor et al. (1993) for the North Atlantic bloom experiment of 1989. These parameters were in turn modified from those of Taylor \& Joint (1990) for a model applied to the Celtic Sea and Porcupine Sea Bight. Although we might hope that a single parameter set would have global application, it is not surprising that these parameters, which had been optimised for the open ocean rather that coastal seas, should not be directly applicable to our planktonic assemblage. However, we found that by numerically optimising the parameters in Table 3 , a more acceptable simulation was obtained. This indicates that for bulk simulation purposes we might hope to assemble a generic parameter set that will require only minor modification for the region or ecosystem to which it is applied.

Following optimisation of the parameter set, many of the characteristics of the mesocosm data in both sets of nutrient conditions could be well reproduced by this single-nutrient $(\mathrm{N})$ Monod-style model. Yet a major discrepancy between data and model remained in that the diatom biomass was predicted to increase continuously throughout the experiments. A parametersensitivity analysis indicated that this continued production was fuelled by the addition of new, N-replete, water. The diatoms were always able to outcompete other autotrophs for this new N, and hence continually increased in biomass over the timescale of the simulations. No modification of parameter values within biologically reasonable limits was able to change these general trends in TMM-1 prediction.

Including a second nutrient, $\mathrm{Si}$, within our Monod structure (as TMM-2) rectified the problem of the predicted continuous increase in diatom biomass. In high $\mathrm{N}: \mathrm{Si}$ mesocosms, the diatoms were thought to be Silimited based on the accumulated evidence of increasing $\mathrm{C}: \mathrm{N}$ ratio, change in cellular glucan content and the concentration of inorganic nutrient in relation to its half-saturation constant (Escarvage et al. 1999, L. C. Gilpin et al. unpubl.). The exhaustion of extracellular $\mathrm{Si}$ in the model led it to predict this Si-yield-limitation of diatom biomass with the resultant cessation in net increase in accordance with the data. In low $\mathrm{N}: \mathrm{Si}$ mesocosms, changes in the $\mathrm{C}: \mathrm{N}$ ratio and intracellular glucan concentration suggested $\mathrm{N}$ limitation. How- ever, when $\mathrm{Si}$ is reduced to low concentrations it is less readily assimilated; its inclusion in the model therefore reduced the tendency of the diatoms to overutilise extracellular $\mathrm{N}$, and hence moderated predicted diatom biomass increase and allowed the other autotroph groups to become established in the model.

Our mesocosms simulate what is a fairly typical coastal scenario, high pre-bloom nutrient concentrations and a continual nutrient input from riverine or other anthropogenic sources. The continued $\mathrm{C}$ biomass increase and resultant overestimate of total predicted $\mathrm{C}$ prior to the incorporation of the second nutrient indicated that a minimum level of sophistication required by the model was a dual inorganic nutrient currency. Simple single-nutrient currency models may overestimate microbial biomass subsequent to the onset of nutrient limitation. As a consequence of the dual nutrient currency, the model predicted the behaviour (also observed by Egge \& Aksnes 1992) of inhibition of diatom growth at low extracellular $\mathrm{Si}$ concentrations.

By varying parameter values (data not shown) we were able to achieve improved simulations of mesocosms in either set of nutrient conditions using this dual N:Si model (TMM-2). However, we were still unable to achieve our goal of a global simulation of both nutrient regimes with a single-model parameterisation. A particular failure was that simulations of high $\mathrm{N}: \mathrm{Si}$ mesocosms underestimated observed diatom C biomass and did not reproduce the observed depletion of inorganic N. Sensitivity-analysis indicated that changes in parameter values that increased the diatom $\mathrm{C}$ yield in high $\mathrm{N}: \mathrm{Si}$ conditions, and hence improved this simulation, had a negative effect on the quality of the simulation in low N:Si conditions, with no single parameter set giving an acceptable fit in both sets of conditions. The inclusion of a dual nutrient currency of $\mathrm{N}$ and Si could therefore be regarded as a necessary but not sufficient step towards a model capable of global simulations.

A feature of the data set was that the maximum yield of diatom $\mathrm{C}$ per unit $\mathrm{N}$ or unit $\mathrm{Si}$ was not constant between different nutrient regimes. Monod-style models make the implicit assumption of a constant $C$ produced per unit limiting nutrient taken up. Our final model (DTQM) introduced the concept of intracellular nutrient pools, cell quotas, on which autotroph biomass growth was based. This allows variation in nutrient:C ratios and luxury consumption of non-limiting nutrients.

The inclusion of cell-quota methodology allowed the prediction of different cell silica and $\mathrm{N}$ content under different conditions. Hence the model predicted a decline in cell silica content at low Si concentrations and enabled higher diatom $\mathrm{C}$ concentrations to be reached in the high $\mathrm{N}: \mathrm{Si}$ mesocosms, with almost all $\mathrm{N}$ 
being taken up. A much-improved simulation of diatom $\mathrm{C}$ and extracellular nutrient concentrations was therefore achieved. Small improvements or effectively no change in the quality of simulation of all other quantities were obtained, with this model being able to achieve our criteria of a satisfactory global simulation (both nutrient regimes) with a single parameter set.

The ability to model the growth of diatoms is of particular importance due to the dominance of diatoms in the spring phytoplankton bloom and their contribution of the majority of new phytoplankton production (Dugdale \& Goering 1967). Our simulations confirm the need for a multiple nutrient currency of $\mathrm{N}$ and $\mathrm{Si}$ and variable nutrient: $\mathrm{C}$ ratios within the modelled diatoms, suggested in a number of other studies. They also give some (although far from conclusive) support for the suggestion that smaller cells in general have smaller half-saturation constants for nutrient uptake. As noted above, in order to model the microcosm data set of Davidson et al. (1999) which followed the interaction between the diatom Thalassiosira pseudonanna, a raphidophyte, and an autotrophic dinoflagellate, Davidson \& Gurney (1999) found it necessary to derive and employ a modified version of the cell quota model. Similarly, Haney \& Jackson (1996) found that the introduction of cell-quota-style growth equations for autotrophs within the model of Fasham et al. (1990) (which originally used Monod functions) significantly changed model predictions, extending through to the heterotrophs to increase the zooplankton population and regenerated production. Other model studies of mesocosm data include those of Baretta-Bekker et al. (1998) and Andersen \& Nival (1989). The former recommended that luxury nutrient uptake and a decoupling of $\mathrm{C}$ and nutrient dynamics be incorporated and the latter that the modelled diatoms should have the ability to store variable amounts of Si.

Although diatoms dominated the mesocosms under both nutrient conditions, a number of conclusions can also be drawn with respect to modelling the other microbial groups. A comparison of the dynamics of non-diatom autotrophs and heterotrophs in isolation from the diatoms is not possible, as the nutrient utilisation by the dominant diatom population fundamentally influences the other organisms in terms of nutrient and prey availability. However, we found the model predictions of the other autotrophs and the heteroptrophs to be robust to changes in formulation. In particular, total heteroptroph biomass and its division between heteroflagellates and larger microzooplankton was well simulated throughout (barring the first set of runs of TMM-1). The improved simulations of phytoflagellates following the incorporation of Si into the model indicated that the inclusion of this nutrient is necessary to allow the prediction not only of the diatoms that utilise it but, critically, the autotrophs that compete with diatoms for $\mathrm{N}$ and the heterotrophs that ingest both. The inclusion of Si moderated the diatom population's ability to utilise $\mathrm{N}$ subsequent to the peak of the bloom, making the $\mathrm{N}$ available for flagellates.

In conclusion, we find that accurate simulation and the ability to respond to change (in our case to alternate inorganic N:Si ratios) of quantities such as C flow, trophic exchange, and nutrient dynamics within our microbial ecosystem requires a biogeochemical modelling approach incorporating a specific representation of different nutrients $(\mathrm{C}, \mathrm{N}, \mathrm{Si})$ both extra- and intracellularly, and the representation of different functional groups within a model. Employing a quotabased model allowed us to satisfactorily simulate the system dynamics under 2 alternative nutrient regimes using only a single-model parameterisation. This indicates the potential suitability of models structured in this way for predictive simulation rather than simple fitting of data.

Acknowledgements. This work was funded by a small grant from the Natural Environment Research Council, UK, and SAMS research funds. It was also supported by the Improving Human Potential-Transnational Access to Research Infrastructures Programme of the European Commission.

\section{LITERATURE CITED}

Andersen V, Nival P (1989) Modelling of phytoplankton population dynamics in an enclosed water column. J Mar Biol Assoc UK 69:625-646

Aure J, Danielssen D, Svendsen E (1998) The origin of Skagerrak coastal water off Arendel in relation to variations in nutrient concentration. ICES J Mar Sci 55:610-619

Azam F (1998) Microbial control of oceanic carbon flux: the plot thickens. Science 280:694-696

Azam F, Fenchel T, Field JG, Gray JS, Meyer-Reil LA, Thingstad F (1983) The ecological role of water-column microbes in the sea. Mar Ecol Prog Ser 10:257-263

Baretta-Bekker JG, Reimann B, Baretta JW, Ramussen EK (1994) Testing the microbial loop concept by comparing mesocosm data with the results from a dynamical simulation model. Mar Ecol Prog Ser 106:187-198

Baretta-Bekker JG, Baretta JW, Hansen AS, Riemann B (1998) An improved model of carbon and nutrient dynamics in the microbial food web in marine enclosures. Aquat Microb Ecol 14:91-108

Brzezinski MA (1985) The Si-C-N ratio of marine diatomsinterspecific variability and the effect of some environmental variables. J Phycol 21:347-357

Caperon J (1968) Population growth in micro-organisms limited by food supply. Ecology 49:715-721

Carr MR (1986) Modelling the attenuation of broad band light down the water column. Statistician 35:325-333

Conley DJ (1997) Riverine contribution of biogenic silica to the oceanic silica budget. Limnol Oceanogr 21:772-777

Conley DJ, Schelske CL, Stoermer EF (1993) Modification of the biogeochemical cycle of silica with eutrophication. Mar Ecol Prog Ser 101:179-192

Conway HL, Harrison PJ, Davis CO (1976) Marine diatoms 
growing in chemostats under silicate or ammonium limitation. II. Transient response of Skeletonema costatum to a single addition of the limiting nutrient. Mar Biol 35: 187-199

Davidson K (1996) Modelling microbial food webs. Mar Ecol Prog Ser 145:279-296

Davidson K, Gurney WSC (1999) An investigation of nonsteady-state algal growth. II. Mathematical modelling of co-nutrient-limited algal growth. J Plankton Res 21: 839-858

Davidson K, Wood G, John EH, Flynn KJ (1999) An investigation of non-steady-state algal growth. I. An experimental model ecosystem. J Plankton Res 21:811-837

Davidson K, Roberts EC, Gilpin LC (2002) The relationship between carbon and biovolume in marine microbial mesocosms under different nutrient regimes. Eur J Phycol 37: $1-7$

Droop MR (1968) Vitamin B-12 and marine ecology. IV. The kinetics of uptake, growth and inhibition in Monochrysis lutheri. J Mar Biol Assoc UK 48:689-733

Dugdale RC, Goering JJ (1967) Uptake of new and regenerated forms of nitrogen in primary productivity. Limnol Oceanogr 12:196-206

Egge JK, Asknes DL (1992) Silicate as regulating nutrient in phytoplankton competition. Mar Ecol Prog Ser 83:281-289

Escarvage V, Prins TC, Nijdam C, Smaal AC, Peeters JCH (1999) Response of phytoplankton communities to nitrogen reduction in mesocosm experiments. Mar Ecol Prog Ser 179:187-199

Fasham MJR, Ducklow HW, McKelvie SM (1990) A nitrogenbased model of plankton dynamics in the ocean mixed layer. J Mar Res 48:591-639

Fasham MJR, Boyd PW, Savidge G (1999) Modeling the relative contributions of autotrophs and heterotrophs to carbon flow at a Lagrangian JGOFS station in the Northeast Atlantic: the importance of DOC. Limnol Oceanogr 44: 80-94

Flynn KJ, Fasham MJR, Hipkin CR (1997) Modelling the interactions between ammonium and nitrate uptake in marine phytoplankton. Philos Trans R Soc Lond B Biol Sci 352:1625-1645

Haney JD, Jackson GA (1996) Modelling phytoplankton growth rates. J Plankton Res 18:63-85

Jickells TD (1998) Nutrient biochemistry of the coastal zone. Science 281:217-222

Lancelot C, Billen G (1985) Carbon-nitrogen relationships in nutrient metabolism of coastal marine ecosystems. Adv Aquat Microbiol 3:263-321

Monod J (1942) Recherches sur la croissance des cultures bacteriennes. Herman, Paris

Montagnes DJS, Berges JA, Harrison PJ, Taylor FJR (1994) Estimating carbon, nitrogen, protein, and chlorophyll a from volume in marine phytoplankton. Limnol Oceanogr 39:1044-1060

Officer CB, Ryther JH (1980) The possible importance of silicon in marine eutrophication. Mar Ecol Prog Ser 3:83-91

Olsen S, Paasche E (1986) Variable kinetics of silicon-limited growth in Thalassiosira pseudonanna (Bacillariophyceae) in response to changed chemical composition of the growth medium. Br Phycol J 21:183-180

Editorial responsibility: Otto Kinne (Editor), Oldendorf/Luhe, Germany
Paasche E (1973) Silicon and the ecology of marine plankton diatoms. II. Silicate-uptake kinetics in five diatom species. Mar Biol 19:262-269

Rahm L, Conley D, Sanden P, Wulff F, Stalnake P (1996) Time series analysis of nutrient inputs to the Baltic Sea and changing DSi:DIN ratios. Mar Ecol Prog Ser 130: 221-228

Redfield AC (1963) The influence of organisms on the composition of seawater. In: Hill MN (ed) The sea, Vol II. John Wiley, New York, p 26-77

Schöllhorn E, Granéli E (1996) Influence of different nitrogen to silica ratios and artificial mixing on the structure of a summer phytoplankton community from the Swedish west coast (Gullmar Fjord). J Sea Res 35:159-167

Sherr BF, Sherr EB, Newell SY (1984) Abundance and productivity of heterotrophic nanoplankton in Georgia coastal waters. J Plankton Res 6:195-202

Smayda TJ (1990) Novel and nuisance phytoplankton blooms in the sea: evidence for a global epidemic. In: Granéli E, Sundström B, Edler L, Anderson DM (eds) Toxic marine phytoplankton Elsevier, New York, p 29-40

Sommer U (1986) Nitrate- and silicate-competition among Antarctic phytoplankton. Mar Biol 91:345-351

Sommer U (1991) Comparative nutrient status and competitive interactions of two Antarctic diatoms (Corethron criophilum and Thalassiosira antarctica). J Plankton Res 13: $61-75$

Sommer U (1994) Are marine diatoms favored by high Si-N ratios. Mar Ecol Prog Ser 115:309-315

Spitz YH, Moisan JR, Abbott MR (2001) Configuring an ecosystem model using data from the Bermuda Atlantic time series (BATS). Deep-Sea Res 48:1733-1768

Steele JH (1974) The structure of marine mesocosms. Harvard University Press, Cambridge, MA

Suttle CA, Chan AM, Taylor WD, Harrison PJ (1986) Grazing of planktonic diatoms by microflagellates. J Plankton Res 8:393-398

Taylor AH, Joint IR (1990) A steady-state analysis of the 'microbial loop' in stratified systems. Mar Ecol Prog Ser 59:1-17

Taylor AH, Watson AJ, Ainsworth M, Robertson JE, Turner DR (1991) A modelling investigation of the role of phytoplankton in the balance of carbon at the surface of the North Atlantic. Global Biogeochem Cycles 5:151-171

Taylor AH, Harbour DS, Harris RP, Burkill PH, Edwards ES (1993) Seasonal succession in the pelagic ecosystem of the North Atlantic and the utilization of nitrogen. J Plankton Res 15:875-891

Tett P, Wilson H (2000) From biochemical to ecological models of marine microplankton. J Mar Syst 25:431-446

Thingstad TF, Havskum H (1999) Bacteria-protist interactions and organic matter degradation under P-limited conditions: analysis of an enclosure experiment using a simple model. Limnol Oceanogr 44:62-79

Watts MC, Bigg GR (2001) Modelling and the monitoring of mesocosm experiments: two case studies. J Plankton Res 23:1081-1093

Williams PJleB, Egge JK (1998) The management and behaviour of the mesocosms. Estuar Coast Shelf Sci 46(Suppl A):3-14

Submitted: February 1, 2002; Accepted: November 12, 2002 Proofs received from author(s): March 3, 2003 